\title{
Profitability and Executive Board Turnover in Russian Banks
}

\author{
Aleksandra Kudryashova \\ Leading Expert \\ ORCID \\ E-mail: kudryashovaae@economy.gov.ru \\ Department for Macroeconomic Analysis and Forecasting, \\ Ministry of Economic Development of the Russian Federation, Moscow, Russia
}

\section{Sergey Solntsev}

$\mathrm{PhD}$ in Labour Economics, Deputy Laboratory Head

$\underline{\text { ORCID }}$

E-mail: ssolntsev@hse.ru

Laboratory for Labour Market Studies,

National Research University Higher School of Economics, Moscow, Russia

Financing: this study was conducted under the scope of the project of Labour Market Research Laboratory of the National Research University Higher School of Economics supported by Basic Research Center - National Research University Higher School of Economics.

Journal of Corporate Finance Research, Vol. 13, No. 2, pp. 50-65 (2019)

DOI: https://doi.org/10.17323/j.jcfr.2073-0438.13.2.2019.50-65

Received 23 January 2019 | Peer-reviewed 15 March 2019 | Accepted 3 June 2019 


\section{Profitability and Executive Board Turnover in Russian Banks}

\section{Abstract}

This paper examines profitability as a factor in the turnover of poorly-performing executives in Russian banks, and how this acts as a mechanism of good corporate governance. It is intended to identify and measure the relative effects of different determinants on executive turnover, and thus highlight the practical sets of circumstances where turnover is most likely. A relatively unique perspective on the study of corporate governance, we intend to demonstrate an aspect of corporate accountability for commercial performance and shed light on high-level manifestations of reactive management practices.

In order to construct the most realistic and robust analysis, we will take into account the idiosyncracies of the companies and individuals involved in this process, and also consider the influence of external economic and social developments where appropriate. The empirical data in this research consists of 3251 observations concerning members of the executive boards of the 50 largest Russian banks from 2005 till 2014. Contemporary accounting data and other financial and economic indicators for these companies is weighed alongside personal information about the banks executives. Descriptive statistics and econometric approaches are utilised in order to parse the provided data and construct a comprehensive explanatory model. Our interpretative process includes the application of probit regressions and OLS panel regressions with fixed effects.

The results of this evaluation may be summarised as follows. We found out that a decrease in return on equity (ROE) and a decrease in return on assets (ROA) leads to a higher probability of executive turnover. Changes in the EBITDA to total assets ratio did not correlate with executive turnover probability. State-controlled banks showed a higher executive turnover rate. A greater turnover rate during pre-crisis 2006-2007 may have been caused by banks' demand for new executives, in their ambition to attain extensive growth. A higher turnover rate in 2014 could have been inspired by the economic sanctions again Russia, or influenced by a recent policy of the Central Bank of the Russian Federation aiming at a "clearance" of the banking system. Finally, it was demonstrated that personal characteristics of the members of the executive boards did not have a significant influence on executive turnover probability.

This study contributes to the limited literature in the area by analysing the determinants of turnover of members of the executive boards of banks depending on the profitability of banks and other characteristics. This is the first study of this kind, based on extensive Russian data which allows for the appraisal of the mechanisms of corporate governance. While a primary limitation of this study is that only large banks were included in the sample, the very presentation of these conclusions carries significant weight in terms of defining methodological parameters for future research. This area is ripe for further investigation. For example, it is immediately apparent that the results may be very different for small or medium-sized banks, let alone other kinds of financial and commercial institutions.

Keywords: commercial banks, corporate governance, profitability indicators, executive board, Russian economy JEL classification: G21, G30, J63 


\section{Introduction}

In any system of corporate governance, one of the primary tasks facing decision makers is the creation of mechanisms for the turnover of poorly performing executives. Such a mechanism should create incentives for executives to improve the performance of their companies, for the companies themselves to retain executives who perform well, and provide pathways to identify and dismiss those who are unsatisfactory. This study examines the extent to which these mechanisms operate in the Russian economy. This will be approached in terms of the influence of profitability indicators on the probability of bank executive turnover, i.e. whether executives are likely to be dismissed if the banks led by them show poor financial performance ${ }^{1}$.

The 50 largest banks included in the sample play a major role in the Russian banking system, and account for about $85 \%$ of total banks' assets in the country. Compared with other sectors of the Russian economy, banks are characterised by greater transparency, which relates to legislative requirements for regular disclosure of the main financial indicators of banks' activities. Furthermore, according to Russian legislation ${ }^{2}$, the management of a bank's operations is to be carried out by a collegial executive body (bank executive board) and a sole executive body (chairperson of the bank executive board). The composition of a bank's executive board is coordinated with the Central Bank of the Russian Federation and requires publication on a regular basis. This allows us to focus our research on the turnover of executives (senior managers) of the bank, i.e. chairmen and board members. The choice of the banking sector is also due to the special importance of banks in the economy, their role in raising funds, and their role in providing loans to companies and individuals. The availability of well-functioning banks is essential for the development of the economy as a whole.

As A. Muravyev has aptly noted, Russia is an excellent place to study the process of corporate governance, because the country has significant challenges in the field of effective management, has been constantly influenced by external shocks that have shaken the Russian economy, and also because of reforms in corporate governance it has witnessed in recent decades [1].

Corporate governance mechanisms in the Russian economy have been actively developed since 1999. At that stage, against the background of economic growth, companies began to actively attract new investors (including foreign ones), to allocate their shares and bonds, to sell major equity stakes and to sell whole companies to new owners. This was accompanied by the departure of owners from the operational management of companies, which also stimulated the development of more efficient corporate governance mechanisms. One of the reasons for the global financial crisis of 2007 was poor corporate governance in the largest banks [2]. This led to a decline in the Russian economy at the end of 2008 and posed new challenges for the management of banks. Another shock to the Russisan economy was the imposition of sanctions from the United States and the European Union in 2014, which complicated access to foreign sources of financing.

\section{Review of Empirical Research and Research Hypotheses}

Most of the studies on the influence of profitability and other financial indicators on the change of company executives are based on data from foreign economies. These works can be divided into two large groups, namely those works that study the effect of poor profitability indicators on the probability of a change in performance, and studies that raise the opposite question, i.e. how executive turnover in a company affects profitability (a tertiary but significant aspect to this is the question as to whether newly appointed executives show a better performance than those they replace).

Let us start with the first group of works in which financial and other indicators are considered as a factor potentially influencing the executive turnover. In these works, the company's performance for the reporting period is used as an independent indicator, and whether an executive succeeds in retaining his position as a head of the company or loses it are treated as dependent ones. Thus, it is estimated how effective or ineffective corporate governance mechanisms are functioning with the aim of retaining "good" executives and dismissing "poorly performing" executives.

Warner et al. analysed 269 companies, the shares of which were traded on the New York and American Stock Exchange from 1963 to 1978 [4]. The results show that there is no unambiguous and unidirectional influence of the performance of a company's activity on the change of senior managers. The study of Fee and Hadlock (based on the data of companies on the S\&P500 list for 1993-1998) has shown that the composition of the senior management changes with the deterioration of the company's profitability, and the CEO position is more sensitive to the deterioration of these factors [5]. Companies with good financial performance often retain a team of senior managers. The study of Tran et al., based on the data of 226 Vietnamese firms for 2009-2015, has revealed a negative relationship

\footnotetext{
${ }^{1}$ Turnover of senior managers can be caused by a large number of reasons, and it is not always possible to obtain data on the real reason for an executive turnover. Among the studies on Russian data, the work of Rachinsky should be mentioned, in which data on the reasons for the executive turnover in Russian companies have been collected and analysed [3]. This study uses a different approach, which is to analyse the factors of the turnover of executives based on large samples, when they are used to estimate the probability of the turnover of an executive depending on the performance of the companies. A description of studies using a similar approach is given in the next section.

${ }^{2}$ The Federal Law “On Banks and Banking Activities” dated 02.12.1990 N 395-1-FZ.
} 
between the indicators of a company's profitability and executive turnover [6]. For the CEO, this relationship was more significant compared to other senior managers.

Among the authors of the second group of works there is no consensus as to the direction of the influence of turnover of executive board members on profitability and other company indicators. There is a perception that turnovers have a positive impact on the company's performance, because new executives contribute their experience and bring new insights fresh ideas to the company. New managers are capable of instilling openness to innovation in companies and increasing their adaptability to environmental changes. They can bring innovations to the company's strategy, a willingness to modify production processes, fight its bottlenecks and achieve better results. Davidson and his co-authors analysed data on 367 key managers of companies that were on the Fortune 500 list in 1986, and noted a positive relationship [7].

On the other hand, Hannan and Freeman are confident that executive board turnover has more of a negative effect. Involving new members in an existing team is not a fast process, it can shake the integrity and efficiency of teamwork [8]. Based on data from 262 fast food restaurants, it was found that the change of executives leads to a decrease in profitability and a deterioration in other indicators of the company [9]. Another study showed that executive board turnover can adversely affect the return on assets (ROA) [10].

The study of Adams and Mehran raises the question of how corporate governance (in particular, the executive board turnover in case of poor performance) in banks differs from similar mechanisms in other sectors of the economy (primarily in industry) [11]. Adams and Mehran did not reveal a similar relationship. The result of their research on data on banking holdings in the United States in 1986-1996 showed a lack of relationship with the executive board turnover in banks in the event of poor financial results. In earlier work on a sample of 83 major US commercial banks for 1982-1987, a positive relationship was found between executive turnover probability and poor performance [12].

After 2008, there were works studying corporate governance in banks and the impact of the global financial crisis on it, which affected the banking system of each country to a varying extent. Beltratti and Stulz did not find confirmation that corporate governance is better in banks. It was found, rather, that boards of directors mostly acted for the benefit of investors before the crisis: the banks, shares of which grew rapidly in 2006, were hardest hit during the crisis [13]. The research on corporate governance in the largest US banks during the 2008 crisis showed that well-functioning corporate governance mechanisms in banks made it possible to derive large profits and smooth out the negative impact of crises [14]. Stepanova and Ivantsova, using data on European banks, revealed that small boards of directors showed better performance during the 2008 crisis [15].
There are relatively few works using data from domestic Russian companies. Goltsman, in her study of the chairman board turnover in large domestic companies, analysed the influence of financial indicators and the ownership structure [16]. Among financial indicators, profitability and change in revenue were significant in the model, and labour productivity was not. Also, the senior manager turnover probability is significantly influenced by a change of owner, and percentage of shares held was not significant. A higher share of state ownership was found to increase executive turnover probability. In the work of Muravyev, based on data on 419 Russian companies, a positive influence of the state as an owner on executive turnover was also found [17].

The relationship between financial performance and executive turnover was found by analysing case study data collected from 110 companies for the years 1997 to 2001 [3]. Research on panel data for the years 1997 to 2003 confirmed the negative relationship between the financial performance of the company and executive turnover [18]. An analysis of the ownership structure has shown that the greater the ownership share investors have in relation to the company, the more probable the turnover of executives. The positive effect of the quality of corporate governance on the results of evaluating the company's market value was confirmed by an empirical analysis of data for 100 Russian companies [19].

The work of Pentyuk and Solntsev on Russian companies that are listed on foreign exchanges in 2003-2013, showed that a poor return on assets value (ROA) increases the probability of a company's CEO turnover [20]. The decline in the company's market capitalisation was found to be an insignificant factor. In the crisis years, there was more activity in terms of replacement of company executives with crisis managers. Analysis of the structure and performance of corporate governance in traded Russian companies based on data collected from 1998 to 2014 was carried out in the article by Muravyev [1]. Empirical analysis is based on data from companies that have ever traded on the RTS and MICEX (Moscow Exchange since 2011). The data are taken from quarterly reports, and contain the full names of managers, their dates of birth, the ownership share and work experience for the previous five years. It was found that there was a reduction in the board size, the share of ownership held by managers, as well as an increase in the share of women and foreigners in the ranks of executives.

Based on the review of the research, the following three hypotheses were suggested.

Hypothesis 1. In case of the deterioration of a bank's profitability, the probability of senior management turnover increases.

This is the main hypothesis of this study, which makes it possible to assess how well corporate governance mechanisms work in Russian banks. Most of the earlier studies on Russian companies, a review of which is given above, support this hypothesis $[16,18,20]$. 
Figure 1. Observations by years

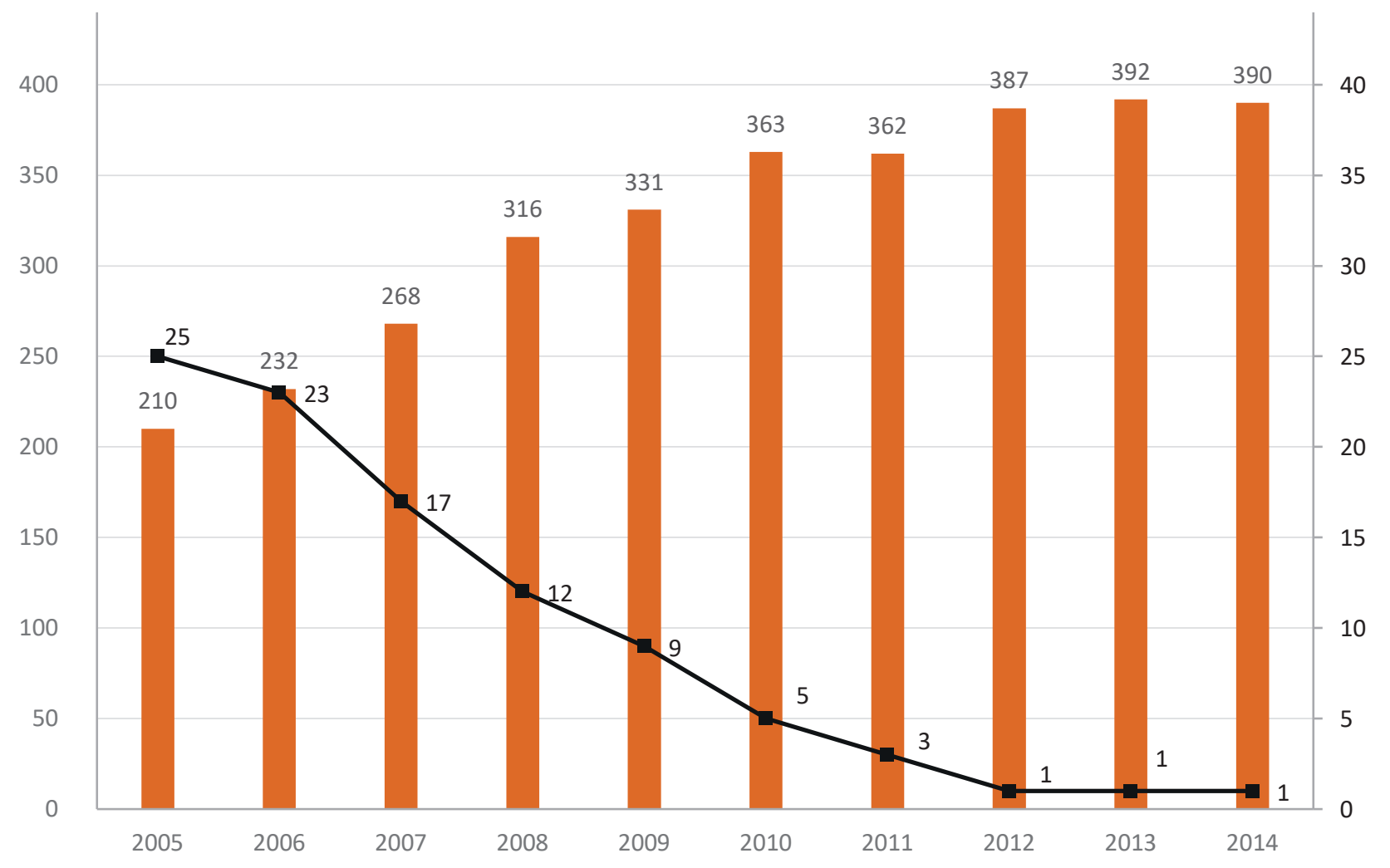

Number of Observations (Executive Board Members)

- Missing Observations (Banks- Right Axis)

Hypothesis 2. During crisis periods, turnover of executive board members in the banking sector increases.

This hypothesis is based on the data obtained concerning Russian traded companies, that during the crisis years there was a higher executive turnover rate [20].

Hypothesis 3. In banks with state participation, turnover rate is higher than in fully private banks with Russian or foreign control.

Although within traditional models, the state has traditionally been perceived as a passive owner, (which creates less incentive for bank management to improve financial performance), for countries with transitional economies the results have shown a high efficiency of banks with state participation [15]. They also show a higher executive turnover rate in companies with state participation $[16,17]$.

As part of this study, we analysed whether corporate governance mechanisms regarding turnover of poor-performance executives work, and how other factors influence executive turnover in Russian banks.

\section{Data and Descriptive Statistics}

For the purpose of empirical analysis, we collected an original database on the executive turnover in Russian banks and indicators of banks' profitability. For the sampling of banks, the rankings prepared by the Expert $R A$ rating agency as of 01.10.2015 was used, in which the banks were arranged in descending order of assets ${ }^{3}$. A total of 747 banks were included in the rating, from which we selected 50 of the largest. Since the information on profitability and board members for three of the 50 largest banks (NCC Bank (ranked 9), Citibank (20), RosEvroBank (48)) was not available for the study period from 2005 to 2014, the sample was modified, with the addition of the banks next on the list (MSP Bank (ranked 51), CB DeltaCredit (52), and the Asia-Pacific Bank (53). A complete list of banks is given in the Appendix. Since the banking system in Russia is characterised by a high degree of bank concentration, the assets of the 50 largest banks included in our sample amount to 65 trillion ruble, i.e. about $85 \%$ of the assets of all banks in Russia (data for 2015).

For the sample of 50 banks obtained, information was collected for a ten-year period (2005-2014) on the management of the banks (board members) and on their main financial performance. Information about the bank board members was obtained from the annual and quarterly reports of banks posted on the websites of banks and in the Spark-Interfax system.

\footnotetext{
${ }^{3}$ The bank ranking is available at http://raexpert.ru/ratings/bank/monthly/Oct2015/ (Verified on 01.03.2018).
} 
Table 1. List of dependent and independent variables

Variable Description of Variable

\section{Dependent variables}

Change

Change_Share

2. Independent variables

\section{2a. Bank profitability indicators}

\begin{tabular}{|c|c|}
\hline EBITDA/Tot_Assets & $\begin{array}{l}\text { Bank earnings before interest expenses, taxes, and amortisation (EBITDA), to the } \\
\text { bank total assets ratio }\end{array}$ \\
\hline$\Delta$ EBITDA Tot_Assets & Change in EBITDA/Tot_Assets compared to last year \\
\hline ROA & Return on Bank Assets \\
\hline$\Delta \mathrm{ROA}$ & Change in ROA compared to last year \\
\hline $\mathrm{ROE}$ & Return on Bank Equity \\
\hline$\Delta \mathrm{ROE}$ & Change in ROE compared with last year \\
\hline
\end{tabular}

\section{2b. Financial indicators of the bank}

C_Equity/Tot_Assets Common Equity/Total Assets, financial independence ratio shows the share of assets secured by the bank's own funds.

$\Delta$ C_Equity/Tot_Assets Change in C_Equity / Tot_Assets compared with last year

Loans/Deposits Loan-to-deposit ratio.

$\Delta$ Loans/Deposits Change in Loans/Deposits compared with last year

Tot_Assets Total bank assets

$\Delta$ Tot_Assets Change in Tot_Assets compared to last year

2c. Characteristics of the members of the bank executive board

Chairperson Dummy variable, equal to 1 for the chairperson of the board and 0 for other members

Age Age of a board member (years)

Experience $\quad$ Work experience on the bank executive board (years)

Gender Gender of a board member: 0 - for women, 1 - for men

Nation Dummy variable for board member citizenship:

0 - foreigner, 1 - citizen of the Russian Federation.

Stocks $\quad$ Percentage of shares of the bank held by the member of the board (\%)

2d. Characteristics of the bank

$\begin{array}{ll}\text { Board_size } & \text { Number of members on the bank executive board } \\ & \text { Bank's form of ownership: } \\ & 0 \text { - Russian private bank, } \\ & 1 \text { - state-controlled bank } \\ & 2 \text { - foreign-controlled bank } \\ & \end{array}$

I The bank was classified as a foreign bank, if it was under the control or significant influence of persons and organisations registered outside the Russian Federation, mainly Russian subsidiaries of foreign banks. The bank was classified as a state bank if the share of federal or regional authorities (directly or indirectly) exceeded 50\%. The data was obtained from the website of the Central Bank of the Russian Federation in the section "Reference book on credit organisations". 
Table 2. Descriptive statistics of dependent and independent variables

\begin{tabular}{|c|c|c|c|c|c|}
\hline & $\begin{array}{l}\text { Number of } \\
\text { observations }\end{array}$ & Mean & $\begin{array}{l}\text { Standard } \\
\text { deviation }\end{array}$ & Minimum & Maximum \\
\hline Change & 3,203 & 0.164 & 0.369 & 0 & 1 \\
\hline Change_Share & 3,186 & 0.165 & 0.198 & 0 & 1 \\
\hline EBITDA/ Tot_Assets & 1,895 & 0.024 & 0.019 & -0.017 & 0.059 \\
\hline$\Delta$ EBITDA/Tot_Assets & 1,657 & -0.015 & 0.832 & -1.755 & 1.969 \\
\hline $\mathrm{ROA}$ & 2,189 & 0.011 & 0.013 & -0.021 & 0.034 \\
\hline$\Delta \mathrm{ROA}$ & 1,960 & -0.239 & 1.787 & -5.883 & 3.191 \\
\hline $\mathrm{ROE}$ & 2,174 & 0.107 & 0.110 & -0.140 & 0.306 \\
\hline$\Delta \mathrm{ROE}$ & 1,950 & -0.174 & 1.585 & -4.890 & 3.115 \\
\hline C_Equity/ Tot_Assets & 2,584 & 10.693 & 3.266 & 5.171 & 18.175 \\
\hline$\Delta \mathrm{C} \_$Equity/Tot_Assets & 2,243 & -0.030 & 0.221 & -0.423 & 0.447 \\
\hline Loans/Deposits & 2,382 & 121.825 & 35.817 & 80.662 & 221.044 \\
\hline$\Delta$ Loans/Deposits & 2,002 & 0.010 & 0.138 & -0.254 & 0.292 \\
\hline Tot_Assets & 2,590 & 974,342 & $1,718,924$ & 52,688 & $6,736,482$ \\
\hline$\Delta$ Tot_Assets & 2,250 & 0.281 & 0,257 & -0.082 & 0.901 \\
\hline Age & 3,174 & 44.18 & 8,016 & 25 & 72 \\
\hline Experience & 3,225 & 4.094 & 3,894 & 0 & 23 \\
\hline Gender & 3,225 & 0.779 & 0.415 & 0 & 1 \\
\hline Nation & 3,224 & 0.968 & 0.176 & 0 & 1 \\
\hline Stocks & 3,205 & 0.445 & 2,858 & 0 & 38.37 \\
\hline Board_size & 3,251 & 9.366 & 3,981 & 2 & 23 \\
\hline
\end{tabular}

The financial indicators of the banks were collected from Ruslana (Bureau van Dijk), Bloomberg and Thomson Reuters databases.

The sample amounted to 3251 observations $^{4}$, and the observations by year are presented in Fig. 1. It is worth noting that in the first two years of observations (2005 and 2006) there is a fairly large number of gaps in the sample which limits the representativeness of the results for this period. In later years, the number of gaps has been reduced, while the number of observations has been increased.

To verify our hypotheses, a probit regression is used in the work within which the probability of the change of a bank board member (Change) is assessed depending on changes in bank profitability indicators (Profit), other financial indicators (FinIndex), characteristics of board members (Personal), and bank characteristics (Bank), as well as the year of observation (Year):

$$
\begin{aligned}
& \text { Probit } \left.\text { Change }_{\mathrm{i}(\mathrm{t}+1)}\right)=\alpha_{1}+\alpha_{2} \cdot \Delta \text { Profit }_{\mathrm{it}}+ \\
& +\alpha_{3} \cdot \Delta \text { FinIndex }_{\mathrm{it}}+\alpha_{4} \cdot \text { Pesonal }_{\mathrm{it}}+ \\
& +\alpha_{5} \cdot \text { Bank }_{\mathrm{it}}+\alpha_{6} \cdot \text { Year. }
\end{aligned}
$$

Since, within this regression, we consider the changing (or retention) of a board member depending on the performance of the bank's activities, the dependent variable is used over the year $t+1$, and the independent variables are used over the year t. EBITDA/Total_Assets, ROA, ROE were used as indicators of bank profitability. We used Common Equity/Total Assets, Loans/Deposits, Total

\footnotetext{
${ }^{4}$ One observation is a board member who held his position as of the end of the calendar year.
} 
Assets as benchmark financial indicators. The characteristics of board members included gender, citizenship, work experience on the board, the position of chairman of the bank, and the share of the bank's ownership. Variables, related to the number of the bank board members and the bank's ownership form were also included. Table 1 shows description of the dependent and independent variables that were used in our analysis of the determinants of turnover of the members of executive boards in Russian banks.

The profitability of banks was assessed by three standard indicators: EBITDA/Tot_Assets, ROA, ROE, which make it possible to view the efficiency of the bank from different perspectives. Return on assets (ROA) characterises the capability of a bank to generate profits. Return on equity (ROE) shows how effectively the capital is used (not the total capital, but the part held by the owners of the bank). The EBITDA-to-assets ratio shows how effectively a bank generates a profit (before interest expenses, taxes, depreciation and amortisation). The financial independence ratio (C_Equity/Tot_Assets) shows the share of assets secured by the bank's own funds. It can be assumed that with the deterioration of this indicator, the turnover probability for board members increases as the organisation's financial sustainability decreases. The size of the bank's total assets (Tot_Assets) indicates the position held by the bank in the market. The loan-to-deposit ratio (Loans/Deposits) is the most important indicator of long-term liquidity of the bank. The high value of this indicator indicates the growing dependence of the bank on foreign markets and sources of financing, which should result in an increase in the turnover probability for the executive board member of the bank. However, the low value of this indicator also demonstrates the inefficient use of funds and receiving less profit by the bank.

Since there is a large variability in values of indicators of profitability of banks and financial indicators, in order to control outliers the winsorizing of $5 \%$ of the minimum and $5 \%$ of the maximum values was made. Table 2 shows descriptive statistics on the variables used in the work. During the period under review, $16.5 \%$ of the board members were changed annually (Table 2). Turnover peaks accounted for 2006-2007, and the same effect took place in 2014 (Figure 2). Higher turnover rates were recorded in state and foreign banks in the first half of the period under review.

Figure 2. Turnover of executive board members by years and the form of ownership of the bank

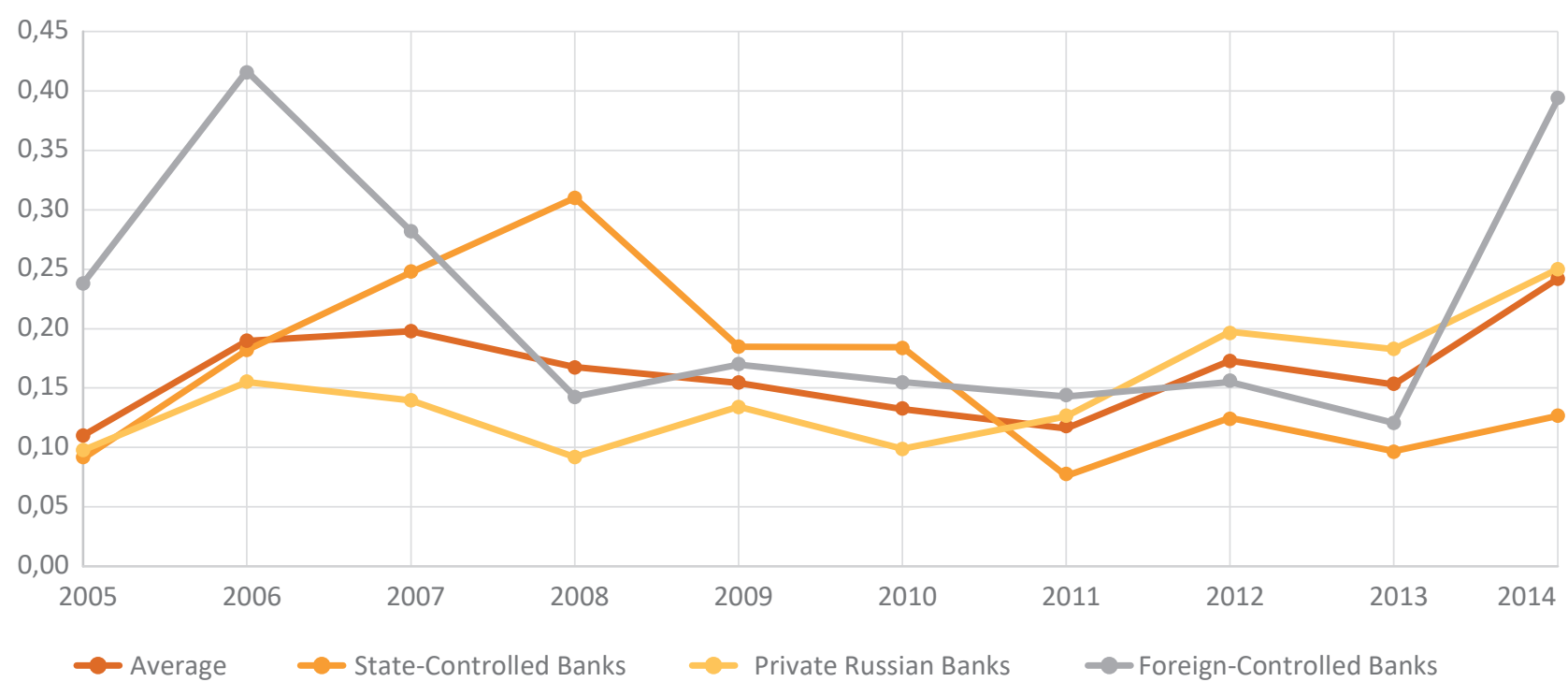

With regard to the individual characteristics of the board members, it can be noted that the average age is 44.2 years (minimum - 25 years, maximum -72 years) (Table 2 ), which generally correlates with the data in the study by Muravyev [1]. Work experience on the bank executive board is in the range of 0 to 23 years, but on average, it amounts to 3-4 years on the board. The percentage of shares held is small and on average is around $0.5 \%$, and the majority of board members do not own shares in the bank managed by them.

The number of members on the board changes from year to year, from two people in some banks, up to 23 in others (Figure 3). On average, the number of executive board members was about 9-10 persons. We can note a slight leap in the number of the board members in 2008, which is combined with an increase in the turnover rate in 2007 (Figure 3). Figure 4 shows the proportion of women and men by years. The proportion of female executive board members was $21.8 \%$ in the sample, varying slightly during the period under review within the range of $19-23 \%$. The same indicator for 212 major US banks for the years 1997-2004 was 5.9\% [21], which is significantly lower than the observed indicator. In our sample, the highest proportion of women was observed in banks with foreign participation, at $26 \%$. In private Russian banks, by contrast, the figure is $23 \%$, and in state-controlled banks, $17 \%$. 
Figure 3. Number of executive board members of the bank (minimum, maximum, mean)

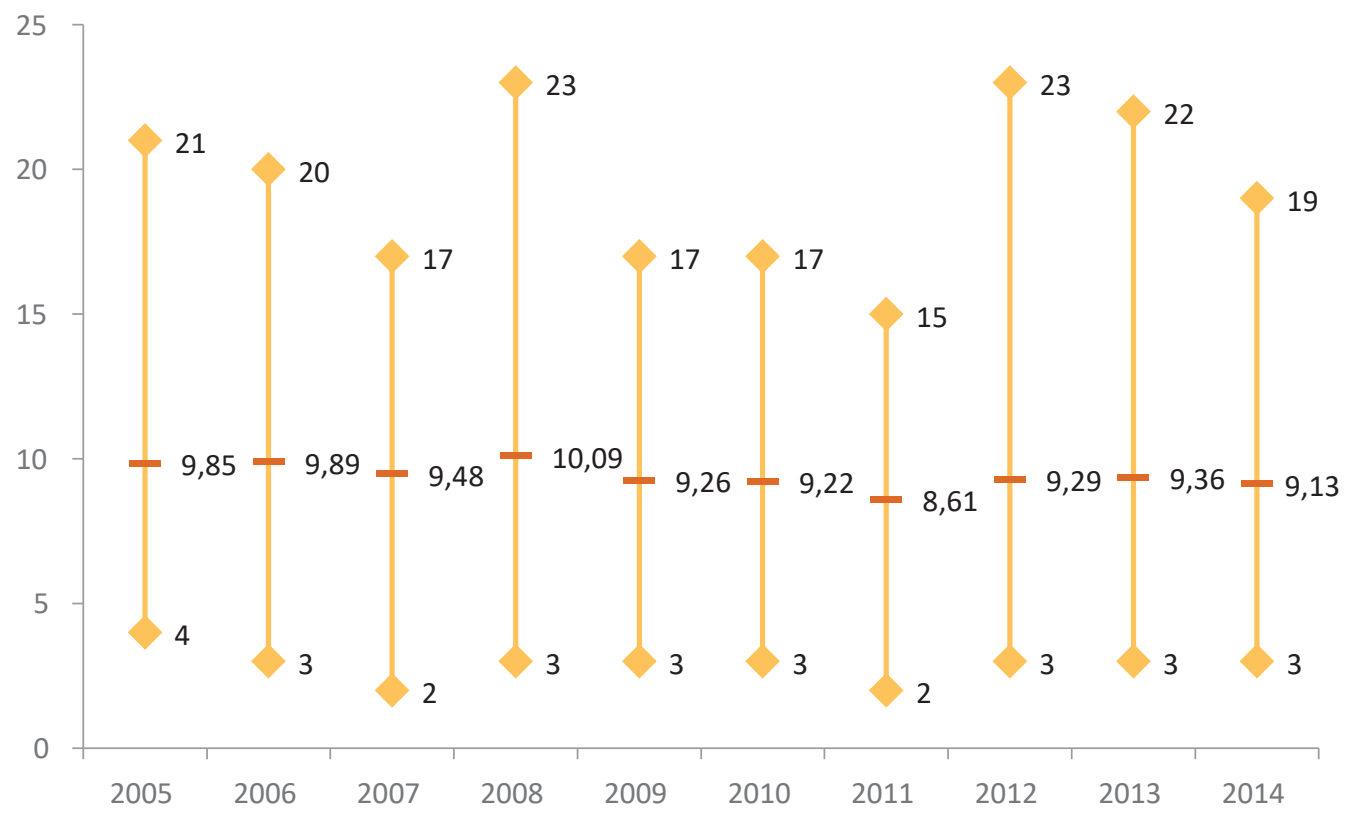

Figure 4. Gender composition of executive board

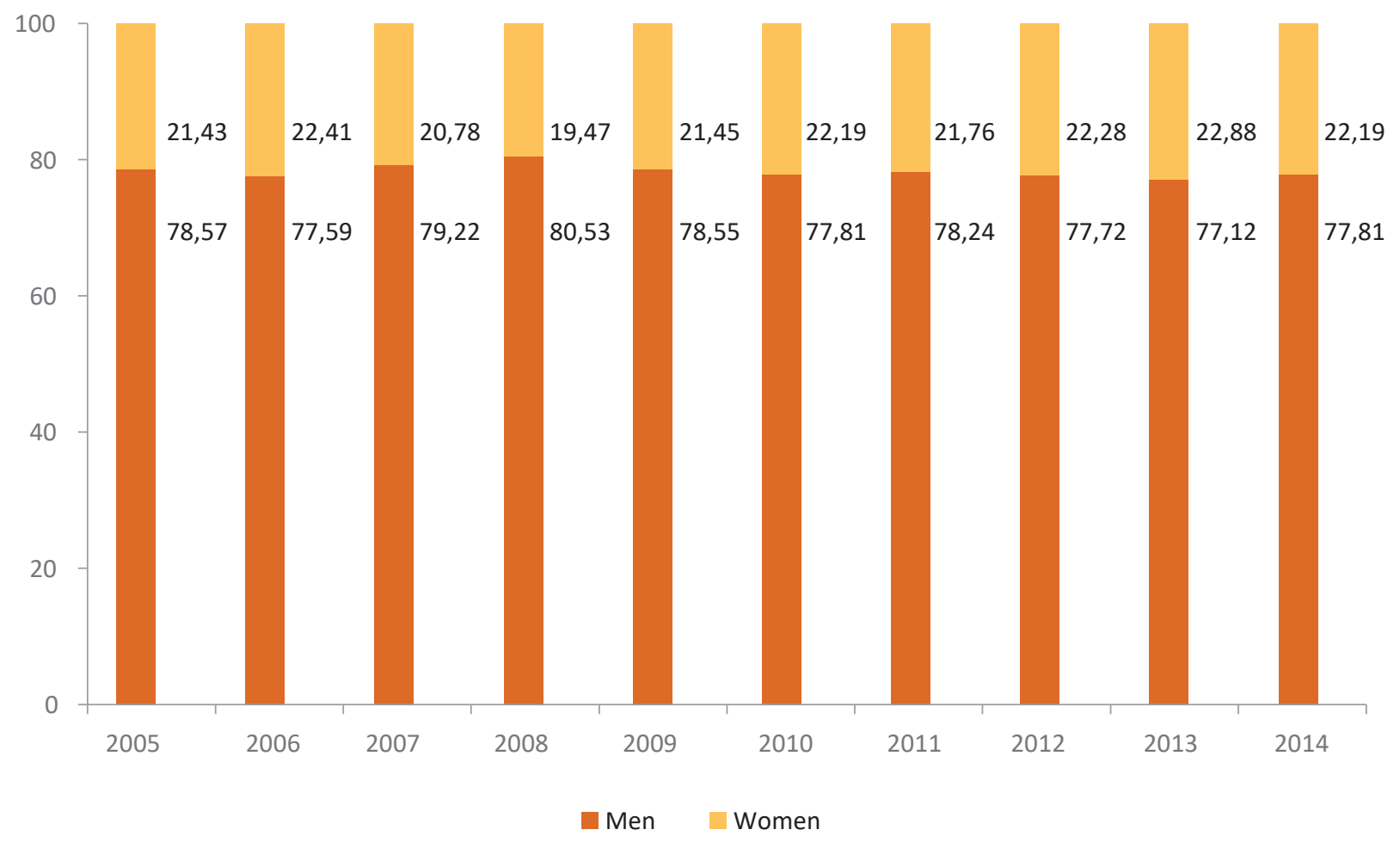

Analysis of the mean values of profitability indicators for 2005-2014 (Figure 5) shows that their dynamics were quite similar. There was a significant drop in performance in 2008, when the economy suffered a decline, followed by stabilisation and a slight increase in the following years and also in 2014 when problems emerged in the economy. 
Figure 5. Dynamics of mean values of EBITDA/Tot_Assets, ROA, ROE

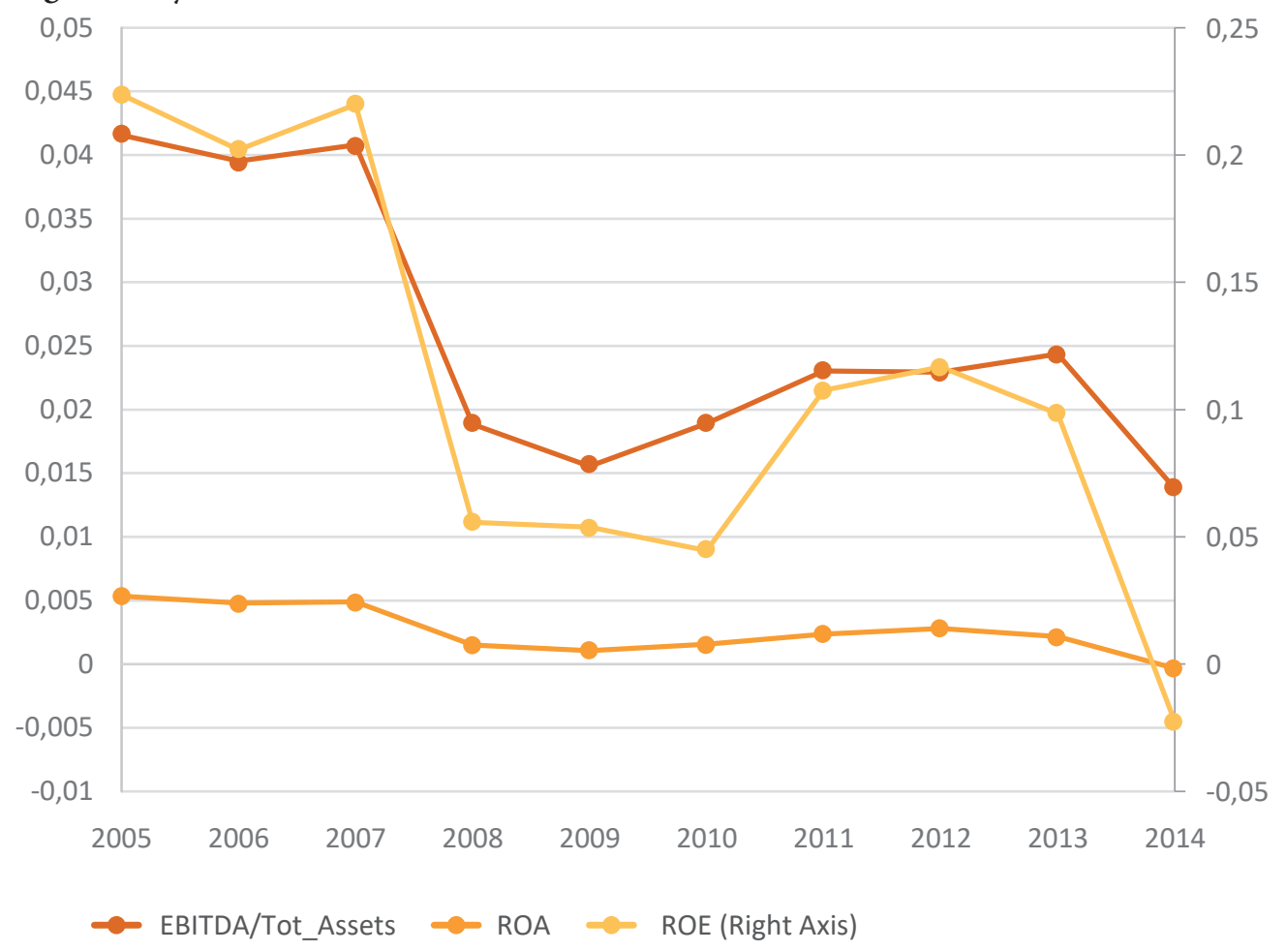

\section{Econometric Analysis}

To verify the hypotheses made, three basic specifications of probit models were evaluated, in which the change of a bank board member (Change) acts as a dependent variable, and the change in bank profitability indicators, the characteristics of a board member, and the year of observation (Table 3) serve as independent variables. The first specification uses $\triangle$ EBITDA/Tot_Assets, specification (2) $-\triangle \mathrm{ROA}$, specification (3) $-\Delta \mathrm{ROE}$. Three variables characterising profitability are added in turn to avoid the effect of correlation. For profitability indicators, relative indicators have been included, which better show the performance of the bank executive board. This indicator also makes it possible to compare disparate banks among themselves. Also, three financial variables are used that characterise various aspects of bank activities $\left(\Delta \mathrm{C} \_\right.$Equity / Tot_Assets, $\Delta$ Loans / Deposits, $\Delta$ Tot_Assets), which were also included in a relative form. The age variables (Age), experience in the board (Experience), year of observation (Year), bank ownership forms (Own) were converted to categorical. One of the values was selected as the baseline, and the others were included into the regression as dummy variables. The variables of gender (Gender), nationality (Nation), bank stocks holding (Stocks), and holding of the position of a board chairman (Chairman) were added to the regression in the form of dummy variables. The board size variable was included into the regression in the form of a logarithm (Board size).

Table 3. Determinants of turnover of executive board members: probit regressions

\begin{tabular}{|c|c|c|c|}
\hline dependant variable - CHANGE & (1) & (2) & (3) \\
\hline$\triangle$ EBITDA/TOT_ASSETs & $\begin{array}{l}-0.003 \\
(0.013)\end{array}$ & & \\
\hline$\triangle \mathrm{ROA}$ & & $\begin{array}{l}-0.014^{* *} \\
(0.005)\end{array}$ & \\
\hline$\Delta \mathrm{ROE}$ & & & $\begin{array}{l}-0.012^{\star *} \\
(0.006)\end{array}$ \\
\hline$\Delta \mathrm{C} \_$Equity/Tot_Assets & $\begin{array}{l}-0.003 \\
(0.004)\end{array}$ & $\begin{array}{l}-0.001 \\
(0.004)\end{array}$ & $\begin{array}{l}-0.001 \\
(0.004)\end{array}$ \\
\hline
\end{tabular}




\begin{tabular}{|c|c|c|c|}
\hline dependant variable - CHANGE & (1) & $(2)$ & (3) \\
\hline \multirow{2}{*}{$\Delta$ Loans/Deposits } & 0.000 & $0.001^{\star}$ & $0.001^{\star}$ \\
\hline & $(0.000)$ & $(0.000)$ & $(0.000)$ \\
\hline \multirow{2}{*}{$\Delta$ Tot_Assets } & 0.000 & 0.000 & 0.000 \\
\hline & $(0.000)$ & $(0.000)$ & $(0.000)$ \\
\hline \multirow{2}{*}{ Board_Size } & $-0.064^{*}$ & -0.027 & -0.026 \\
\hline & $(0.035)$ & $(0.029)$ & $(0.029)$ \\
\hline \multicolumn{4}{|l|}{ Age (35 or less) } \\
\hline \multirow{2}{*}{$36-40$} & -0.051 & -0.030 & -0.030 \\
\hline & $(0.043)$ & $(0.037)$ & $(0.037)$ \\
\hline \multirow{2}{*}{$41-45$} & $-0.077^{\star}$ & -0.051 & -0.051 \\
\hline & $(0.043)$ & $(0.037)$ & $(0.037)$ \\
\hline \multirow{2}{*}{$46-51$} & -0.060 & -0.043 & -0.043 \\
\hline & $(0.044)$ & $(0.038)$ & $(0.038)$ \\
\hline \multirow{2}{*}{52 or more } & -0.007 & 0.006 & 0.007 \\
\hline & $(0.047)$ & $(0.041)$ & $(0.041)$ \\
\hline \multirow{2}{*}{ Gender } & -0.007 & 0.006 & 0.007 \\
\hline & $(0.047)$ & $(0.041)$ & $(0.041)$ \\
\hline \multicolumn{4}{|l|}{ EXPERIENCE (0-0.9) } \\
\hline \multirow{2}{*}{$1-1.9$} & 0.016 & -0.001 & -0.001 \\
\hline & $(0.033)$ & $(0.031)$ & $(0.031)$ \\
\hline \multirow{2}{*}{$2-3.9$} & -0.002 & -0.004 & -0.003 \\
\hline & $(0.029)$ & $(0.028)$ & $(0.028)$ \\
\hline \multirow{2}{*}{$4-6.9$} & 0.036 & 0.023 & 0.023 \\
\hline & $(0.032)$ & $(0.031)$ & $(0.031)$ \\
\hline \multirow{2}{*}{7 or more } & $0.084^{\star *}$ & 0.051 & 0.052 \\
\hline & $(0.035)$ & $(0.032)$ & $(0.032)$ \\
\hline \multicolumn{4}{|l|}{ Own (0 - PRIVATE Russian) } \\
\hline \multirow{2}{*}{1 (STATE-controlled) } & 0.005 & -0.006 & -0.004 \\
\hline & $(0.029)$ & $(0.026)$ & $(0.026)$ \\
\hline \multirow{2}{*}{2 (Foreign-controlled) } & 0.071 & 0.051 & 0.053 \\
\hline & $(0.043)$ & $(0.036)$ & $(0.036)$ \\
\hline \multicolumn{4}{|l|}{ Year (2011) } \\
\hline \multirow{2}{*}{2006} & $0.152^{\star * *}$ & $0.151^{\star * *}$ & $0.151^{\star * *}$ \\
\hline & $(0.057)$ & $(0.057)$ & $(0.058)$ \\
\hline \multirow{2}{*}{2007} & $0.144^{\star * *}$ & $0.107^{\star \star}$ & $0.106^{\star *}$ \\
\hline & $(0.051)$ & $(0.044)$ & $(0.044)$ \\
\hline
\end{tabular}




\begin{tabular}{|c|c|c|c|}
\hline dependant variable - CHANGE & (1) & (2) & (3) \\
\hline 2008 & $\begin{array}{l}0.089^{* *} \\
(0.042)\end{array}$ & $\begin{array}{l}0.070^{*} \\
(0.038)\end{array}$ & $\begin{array}{l}0.067^{\star} \\
(0.038)\end{array}$ \\
\hline 2009 & $\begin{array}{l}0.056 \\
(0.036)\end{array}$ & $\begin{array}{l}0.033 \\
(0.034)\end{array}$ & $\begin{array}{l}0.035 \\
(0.034)\end{array}$ \\
\hline 2010 & $\begin{array}{l}0.102^{* *} \\
(0.040)\end{array}$ & $\begin{array}{l}0.072^{\star *} \\
(0.036)\end{array}$ & $\begin{array}{l}0.071^{\star *} \\
(0.036)\end{array}$ \\
\hline 2012 & $\begin{array}{l}0.077^{\star *} \\
(0.033)\end{array}$ & $\begin{array}{l}0.067^{\star *} \\
(0.031)\end{array}$ & $\begin{array}{l}0.064^{\star *} \\
(0.031)\end{array}$ \\
\hline 2013 & $\begin{array}{l}0.026 \\
(0.029)\end{array}$ & $\begin{array}{l}0.023 \\
(0.028)\end{array}$ & $\begin{array}{l}0.022 \\
(0.028)\end{array}$ \\
\hline 2014 & $\begin{array}{l}0.077^{\star *} \\
(0.033)\end{array}$ & $\begin{array}{l}0.083^{\star *} \\
(0.032)\end{array}$ & $\begin{array}{l}0.087^{\star \star *} \\
(0.033)\end{array}$ \\
\hline Chairperson & $\begin{array}{l}-0.046 \\
(0.029)\end{array}$ & $\begin{array}{l}-0.014 \\
(0.028)\end{array}$ & $\begin{array}{l}-0.014 \\
(0.028)\end{array}$ \\
\hline Stocks & $\begin{array}{l}-0.028 \\
(0.024)\end{array}$ & $\begin{array}{l}-0.016 \\
(0.024)\end{array}$ & $\begin{array}{l}-0.016 \\
(0.024)\end{array}$ \\
\hline Nation & $\begin{array}{l}-0.118 \\
(0.077)\end{array}$ & $\begin{array}{l}-0.153^{\star *} \\
(0.070)\end{array}$ & $\begin{array}{l}-0.152^{\star *} \\
(0.070)\end{array}$ \\
\hline _cons & $\begin{array}{l}-0.241 \\
(0.535)\end{array}$ & $\begin{array}{l}-0.654 \\
(0.465)\end{array}$ & $\begin{array}{l}-0.648 \\
(0.464)\end{array}$ \\
\hline Pseudo $\mathrm{R}^{2}$ & 0.0487 & 0.0461 & 0.0447 \\
\hline Prob $>$ chi $^{2}$ & 0.0002 & 0.0001 & 0.0001 \\
\hline $\mathrm{N}$ & 1,429 & 1,630 & 1,630 \\
\hline
\end{tabular}

Notes: significance level: ${ }^{* *}-1 \%,{ }^{*}-5 \%,{ }^{*}-10 \%$. The table shows the marginal effects - the marginal effects relative to the baseline values are given for categorical variables (the baseline values are shown in parentheses).

As a result of the assessment, the $\triangle \mathrm{ROA}$ and $\triangle \mathrm{ROE}$ variables turned out to be negative (specifications (2) and (3)). That is, with a deterioration in the return on equity value the probability of being replaced increases. This result is quite logical and can be explained by the fact that with the deterioration of the bank's profitability indicators, investors and the board of directors decide to replace pour-performance bank managers. The $\triangle$ EBITDA/Tot_Assets variable was not significant (specification (1)). Thus, we can say that hypothesis 1 is confirmed with regard to ROA and ROE.

In two of the three specifications, the board size logarithm (Board_Size) turned out to be significant, which indicated that the greater the number of people on the board, the less probability of a particular senior manager change. In all specifications, only the third age group was significant, which indicated that compared with young managers under the age of 35 , only managers aged $41-45$ years are less likely to be dismissed. This result is logical and can be explained by the fact that in this age group, managers not only have sufficient experience in solving major problems, but are also active in introducing innovations.

The experience variable in this bank (Experience) was significant only for experience over 7 years (specification (1)). The gender of the manager (Gender), the fact of stocks holding (Stocks) and holding of the position of the board chairperson (Chairperson) were insignificant in all specifications. As for the members of the board, foreigners (Nation) were significantly more likely to lose their position.

As we have seen in the descriptive analysis (Figure 2), 2006, 2007, 2008 and 2014 were significant. In these years there was a higher probability of a board member change, indicating that hypothesis 2 is not confirmed in terms of the 2008-2009 crisis years, but is confirmed regarding 2014. 
The significance of the ratios regarding the form of ownership of the bank (Own) should be noted. In the first specification, we found that in banks with state participation, turnover rate is higher than in Russian private banks, which confirms hypothesis 1 . Specifications (2) and (3) indicate that turnover is increasingly common in foreign-controlled banks compared with private Russian banks.

Further, panel regressions were evaluated. The use of panel data makes it possible to take into account the heterogeneity in banks, the specifics of their operation, and the corporate governance at play in them, and variables which were not taken into account in the control variables in the previous model. The share of the bank board members change (Change_Share) was used as a dependent variable, the board size logarithm (Board_Size), the change in profitability indicators $(\triangle \mathrm{EBITDA} /$ Tot_Assets, $\triangle \mathrm{ROA}$, $\triangle \mathrm{ROE})$, the change in financial indicators ( $\triangle \mathrm{C}$ _Equity/ Tot_Assets, $\Delta$ Loans/Deposits, $\Delta$ Tot_Assets), the year of observation (Year), and the variables of share of women (Woman_Share), and the share of foreigners on the board (Foreign_Share) made for panel regression were used as independent variables. Similar to specifications (1)-(3), profitability indicators are added to the panel regression separately (4)-(6). The specification equation (4) is given below; in the specifications (5), (6), instead of $\triangle$ EBITDA/ Tot_Assets, two other variables characterising profitability $(\triangle \mathrm{ROA}, \triangle \mathrm{ROE})$ are used:

$$
\begin{aligned}
& \text { Change_Share }_{\mathrm{i}(\mathrm{t}+1)}=\alpha_{1}+\alpha_{2} * \text { Board size }_{\mathrm{it}}+ \\
& +\alpha_{3} \cdot \Delta \text { EBITDA } / \text { Tot_Assets } \\
& +\alpha_{5} \cdot \text { Woman_Share }_{\mathrm{it}}+\alpha_{6} \cdot \text { Foreign_Share }_{\mathrm{it}} .
\end{aligned}
$$

As part of the study, OLS panel regression with fixed and random effects were calculated. Regressions with fixed effects have been selected, based on the Hausman test and

\begin{tabular}{|c|c|c|c|}
\hline DEPENDANT VARIABLE - Change_Share & $(4)$ & (5) & $(6)$ \\
\hline$\triangle$ EBITDA/Tot_Assets & $\begin{array}{l}-0.001 \\
(0.020)\end{array}$ & & \\
\hline$\triangle \mathrm{ROA}$ & & $\begin{array}{l}-0.021^{\star *} \\
(0.009)\end{array}$ & \\
\hline$\triangle \mathrm{ROE}$ & & & $\begin{array}{l}-0.019^{*} \\
(0.010)\end{array}$ \\
\hline$\Delta \mathrm{C}$ _Equity/Tot_Assets & $\begin{array}{l}-0.012 \\
(0.009)\end{array}$ & $\begin{array}{l}-0.005 \\
(0.008)\end{array}$ & $\begin{array}{l}-0.006 \\
(0.008)\end{array}$ \\
\hline$\Delta$ Loans/Deposits & $\begin{array}{l}0.001 \\
(0.001)\end{array}$ & $\begin{array}{l}0.001 \\
(0.001)\end{array}$ & $\begin{array}{l}0.001 \\
(0.001)\end{array}$ \\
\hline$\Delta$ Tot_Assets & $\begin{array}{l}-0.000 \\
(0.000)\end{array}$ & $\begin{array}{l}-0.000 \\
(0.000)\end{array}$ & $\begin{array}{l}-0.000 \\
(0.000)\end{array}$ \\
\hline Board_Size & $\begin{array}{l}0.281^{\star *} \\
(0.115)\end{array}$ & $\begin{array}{l}0.295^{\star * *} \\
(0.092)\end{array}$ & $\begin{array}{l}0.292^{\star * *} \\
(0.093)\end{array}$ \\
\hline Woman_Share & $\begin{array}{l}-0.178 \\
(0.202)\end{array}$ & $\begin{array}{l}-0.270 \\
(0.178)\end{array}$ & $\begin{array}{l}-0.258 \\
(0.179)\end{array}$ \\
\hline Foreign_Share & $\begin{array}{l}0.071 \\
(0.337)\end{array}$ & $\begin{array}{l}-0.060 \\
(0.263)\end{array}$ & $\begin{array}{l}-0.070 \\
(0.264)\end{array}$ \\
\hline
\end{tabular}
are presented in Table 4.

Table 4. Determinants of turnover of executive board members: OLS panel regressions

\begin{tabular}{|c|c|c|c|}
\hline \multirow{2}{*}{2006} & 0.108 & 0.074 & 0.074 \\
\hline & $(0.102)$ & $(0.097)$ & $(0.097)$ \\
\hline \multirow{2}{*}{2007} & $0.163^{*}$ & 0.079 & 0.077 \\
\hline & $(0.084)$ & $(0.070)$ & $(0.070)$ \\
\hline
\end{tabular}

Year (2011) 


\begin{tabular}{|c|c|c|c|}
\hline DEPENDANT VARIABLE - Change_Share & (4) & $(5)$ & (6) \\
\hline 2008 & $\begin{array}{l}0.080 \\
(0.074)\end{array}$ & $\begin{array}{l}0.037 \\
(0.067)\end{array}$ & $\begin{array}{l}0.032 \\
(0.067)\end{array}$ \\
\hline 2009 & $\begin{array}{l}0.101 \\
(0.067)\end{array}$ & $\begin{array}{l}0.037 \\
(0.061)\end{array}$ & $\begin{array}{l}0.039 \\
(0.061)\end{array}$ \\
\hline 2010 & $\begin{array}{l}0.116^{*} \\
(0.066)\end{array}$ & $\begin{array}{l}0.078 \\
(0.056)\end{array}$ & $\begin{array}{l}0.075 \\
(0.056)\end{array}$ \\
\hline 2012 & $\begin{array}{l}0.066 \\
(0.055)\end{array}$ & $\begin{array}{l}0.056 \\
(0.049)\end{array}$ & $\begin{array}{l}0.053 \\
(0.049)\end{array}$ \\
\hline 2013 & $\begin{array}{l}0.030 \\
(0.056)\end{array}$ & $\begin{array}{l}0.032 \\
(0.049)\end{array}$ & $\begin{array}{l}0.030 \\
(0.050)\end{array}$ \\
\hline 2014 & $\begin{array}{l}0.109^{\star} \\
(0.061)\end{array}$ & $\begin{array}{l}0.109^{* *} \\
(0.054)\end{array}$ & $\begin{array}{l}0.112^{\star *} \\
(0.055)\end{array}$ \\
\hline _cons & $\begin{array}{l}-0.514^{\star *} \\
(0.279)\end{array}$ & $\begin{array}{l}-0.472^{\star * *} \\
(0.231)\end{array}$ & $\begin{array}{l}-0.458^{* * *} \\
(0.232)\end{array}$ \\
\hline $\mathrm{N}$ & 148 & 181 & 181 \\
\hline
\end{tabular}

Notes: significance level: ${ }^{* *}-1 \%,{ }^{* *}-5 \%,{ }^{*}-10 \%$. The table shows the marginal effects, the marginal effects relative to the baseline values are given for categorical variables (the baseline values are shown in parentheses).

In general, previously obtained results have been confirmed. Among the dummy variables, the years of observation were significant for 2014 (in all three specifications) and 2007 (in specification (4)). The Board_Size variable was significant with a positive sign, i.e. with an increase in the number of board members in a particular bank, the probability of a board member change increases, and with a decrease in the number of board members, the turnover probability decreases. It is expected that the sign before Board_Size has changed as compared with the probit-regressions, since Specifications (1)-(3) (Table 3) compared various banks with different numbers of board members, and Specifications (4)-(4) (Table 4) compared the changes in the number of board members in one bank. The share of foreigners (Foreign_Share) and the share of women (Woman_Share) were not significant.

\section{Conclusion}

This work examined the senior management turnover in the banking sector and evaluated the effectiveness of corporate governance mechanisms in the largest banks in Russia. Based on the original data, three hypotheses were tested using econometric regressions. The dependent variable was the change of the executive board member, and the regressors were the bank profitability indicators (EBITDA/Tot_Assets, ROA and ROE), other characteristics of banks, personal data of board members, the years of observation.
Our analysis has revealed that for two of the three financial indicators a significant effect was found on the probability of a board member change: a decrease in ROE and ROA significantly increases the probability of a change of bank board member, while a change in EBITDA/ Tot_Assets does not have a significant effect on the turnover probability. In general, a weak negative relationship corresponds to earlier work on executive turnover in Russian companies [3, 18, 20].

The higher managerial turnover rate in state-controlled banks confirmed the results obtained on the basis of research on data from the 1990s $[16,17,20]$.

Our hypothesis regarding higher management turnover rates during the crisis did not find its confirmation for the crisis of 2008. This is significant, as higher rates of turnover of executive board members were observed during the period of active growth of the economy $(2006,2007)$ and banks actively involved new managers who were to provide active growth of banks. As such, this result contradicts the conclusion made in the study on Russian companies traded on foreign exchanges [20].

An increased frequency of turnover of executive board members in 2014 can be associated both with the imposition of economic sanctions in 2014, which could require the involvement of managers who can work both in the environment of restricted foreign sources of funding. Further, it cannot be disregarded that this increased frequency is also related to the arrival of a new team led by E.S. Nabiullina and the declared policy of bank's system "clearance" in Russia. 


\section{References}

1. Muravyev A. Boards of directors in Russian publicly traded companies in 1998-2014: Structure, dynamics and performance effects. Economic Systems. 2017;41(1):5-25. DOI: 10.1016/j.ecosys.2016.12.001

2. Laeven L. Corporate governance: What's special about banks? Annual Review of Financial Economics. 2013;5:63-92. DOI: 10.1146/annurevfinancial-021113-074421

3. Rachinsky A. Self-enforced mechanisms of corporate governance: Evidence from managerial turnover in Russia. Centre for Economic and Financial Research Working Paper. 2002;(0051). URL: https://core.ac.uk/ download/pdf/7142759.pdf

4. Warner J.B., Watts R.L., Wruck K.H. Stock prices and top management changes. Journal of Financial Economics. 1988;20(Jan.-Mar.):461-492. DOI: 10.1016/0304-405X(88)90054-2

5. Fee C.E., Hadlock C.J. Management turnover across the corporate hierarchy. Journal of Accounting and Economics. 2004;37(1):3-38. DOI: 10.1016/j. jacceco.2003.11.003

6. Tran Q.T., Nguyen X.M., Nguyen T.H. CEO duality, state shareholder and CEO turnover: Evidence from Vietnamese stock market. Business and Economic Horizons. 2016;12(3):113-120. DOI: 10.15208/ beh.2016.09

7. Davidson W.N. III, Worrell D.L., Cheng L. Key executive succession and stockholder wealth: The influence of successor's origin, position, and age. Journal of Management. 1990;16(3):647-664. DOI: $10.1177 / 014920639001600309$

8. Hannan M.T., Freeman J. Structural inertia and organizational change. American Sociological Review. 1984;49(2):149-164. DOI: 10.2307/2095567

9. Kacmar K.M., Andrews M.C., Van Rooy D.L., Steilberg R.C., Cerrone S. Sure everyone can be replaced... but at what cost? Turnover as a predictor of unit-level performance. The Academy of Management Journal. 2006;49(1):133-144. DOI: $10.2307 / 20159750$

10. Shen W., Cannella A. Power dynamics within top management and their impacts on CEO dismissal followed by inside of succession. The Academy of Management Journal. 2002;45(6):1195-1206. DOI: $10.2307 / 3069434$

11. Adams R.B., Mehran H. Is corporate governance different for bank holding companies? Economic Policy Review. 2003;9(1):123-142. DOI: 10.2139/ ssrn.387561.
12. Barro J.R., Barro R.J. Pay, performance, and turnover of bank CEOs. Journal of Labor Economics. 1990;8(4):448-481. DOI: 10.1086/298230

13. Beltratti A., Stulz R. The credit crisis around the globe: Why did some banks perform better? Journal of Financial Economics. 2012;105(1):1-17. DOI: 10.1016/j.jfineco.2011.12.005

14. Peni E., Vähämaa S. Did good corporate governance improve bank performance during the financial crisis? Journal of Financial Services Research. 2012;41(1-2):19-35. DOI: 10.1007/s10693-011-01089

15. Stepanova A., Ivantsova O. Do large European banks benefit from sound corporate governance in good and bad times? Korporativnye finansy = Journal of Corporate Finance Research. 2016;10(4):28-42. DOI: 10.17323/j.jcfr.2073-0438.10.4.2016.28-42

16. Goltsman M. Empirical analysis of managerial turnover in Russian firms. New Economic School Working Paper. 2000;(BSP/00/035). URL: https:// www.nes.ru/dataupload/files/programs/econ/ preprints/2000/Goltsman_engl.pdf

17. Muravyev A. Turnover of top executives in Russian companies. Russian Economic Trends. 2001;10(1):2024. DOI: $10.1111 / 1467-9426.00162$

18. Kapelyushnikov R., Demina N. Top management turnover in Russian industrial companies: Evidence from the "Russian Economic Barometer". Rossiiskii zhurnal menedzhmenta $=$ Russian Management Journal. 2005;3(3):27-42. (in Russ.).

19. Black B., Love I., Rachinsky A. Corporate governance indices and firms' market values: Time series evidence from Russia. Emerging Markets Review. 2006;7(4):361-379. DOI: 10.1016/j. ememar.2006.09.004

20. Pentyuk A., Solntsev S. Corporate governance in Russia's companies: financial factors of CEO replacement. Problemy teorii i praktiki upravleniya = Theoretical and Practical Aspects of Management . 2016;(1):117-125. (in Russ.).

21. Pathan S., Faff R. Does board structure in banks really affect their performance? Journal of Banking \& Finance. 2013;37(5):1573-1589. DOI: 10.1016/j. jbankfin.2012.12.016 


\section{Appendix}

\section{Ranks of banks (01.10.2015)}

\begin{tabular}{|c|c|c|}
\hline № & Bank name & $\begin{array}{l}\text { Assets, } \\
\text { bln rubles }\end{array}$ \\
\hline 1 & PJSC Sberbank & 22362.4 \\
\hline 2 & VTB Bank (PJSC) & 8732.1 \\
\hline 3 & GPB Bank (JSC) & 4794.8 \\
\hline 4 & $\begin{array}{l}\text { PJSC Bank Otkritie Financial } \\
\text { Corporation }\end{array}$ & 2986.5 \\
\hline 5 & VTB 24 (PJSC) & 2774.1 \\
\hline 6 & JSC Russian Agricultural Bank & 2445.6 \\
\hline 7 & JSC ALFA-BANK & 2133.9 \\
\hline 8 & Bank of Moscow OJSC & 1836.0 \\
\hline 10 & JSC UniCredit Bank & 1368.2 \\
\hline 11 & PJSC Promsvyazbank & 1237.9 \\
\hline 12 & OJSC MOSCOW CREDIT BANK & 1007.5 \\
\hline 13 & PJSC ROSBANK & 892.3 \\
\hline 14 & JSC Raiffeisenbank & 879.2 \\
\hline 15 & PJSC BINBANK & 698.0 \\
\hline 16 & $\begin{array}{l}\text { PJSC Khanty-Mansiysk Bank } \\
\text { Otkritie }\end{array}$ & 609.9 \\
\hline 17 & PJSC “Saint-Petersburg” Bank & 536.9 \\
\hline 18 & JSC “AB» RUSSIA” & 523.9 \\
\hline 19 & PJSC “AK BARS” BANK & 523.9 \\
\hline 21 & JSC Bank Russian Standard & 487.1 \\
\hline 22 & PJSC Sovcombank & 443.2 \\
\hline 23 & ING BANK (EURASIA) JSC & 388.8 \\
\hline 24 & PJSC JSCB Svyaz-Bank & 382.5 \\
\hline 25 & PJSC MOSOBLBANK & 370.9 \\
\hline 26 & JSC Nordea Bank & 369.2 \\
\hline 27 & PJSC BANK URALSIB & 344.6 \\
\hline 28 & PJSC CB UBRD & 342.3 \\
\hline 29 & PJSC MDM Bank & 338.3 \\
\hline 30 & Bank TRUST (PJSC) & 306.1 \\
\hline 31 & ROST BANK JSC & 301.0 \\
\hline 32 & SMP Bank JSC & 299.7 \\
\hline 33 & JSC JSCB NOVIKOMBANK & 295.8 \\
\hline 34 & GLOBEXBANK JSC & 294.9 \\
\hline
\end{tabular}

\begin{tabular}{|c|c|c|}
\hline № & Bank name & $\begin{array}{l}\text { Assets, } \\
\text { bln rubles }\end{array}$ \\
\hline 35 & PJSC BANK UGRA & 293.1 \\
\hline 36 & PJSC Bank ZENIT & 291.7 \\
\hline 37 & Vneshprombank LLC & 285.8 \\
\hline 38 & HCF Bank LLC & 274.3 \\
\hline 39 & JSCB Absolut Bank (PJSC) & 259.3 \\
\hline 40 & AKB RUSSIAN CAPITAL (PJSC) & 256.7 \\
\hline 41 & PJSC MinBank & 225.0 \\
\hline 42 & Vozrozhdenie Bank (PJSC) & 212.9 \\
\hline 43 & PJSC CB Vostochny & 191.0 \\
\hline 44 & $\begin{array}{l}\text { OJSC "Joint-Stock Investment } \\
\text { Bank "Tatfondbank" }\end{array}$ & 184.8 \\
\hline 45 & TKB BANK PJSC & 181.5 \\
\hline 46 & AKB PERESVET (JSC) & 166.5 \\
\hline 47 & PJSC MTS-Bank & 165.3 \\
\hline 49 & JSC OTP Bank & 149.9 \\
\hline 50 & JSC Credit Europe Bank & 143.6 \\
\hline 51 & JSC MSP Bank & 143.0 \\
\hline 52 & JSC CB DeltaCredit & 139.9 \\
\hline 53 & Asia-Pacific Bank» (PJSC) & 138.4 \\
\hline
\end{tabular}

